Elżbieta Pitrus

Uniwersytet Jagiellonski

Zakład Gospodarki Turystycznej i Uzdrowiskowej

ul. Gronostajowa 7, 30-387 Kraków

epitrus@geo.uj.edu.pl

\section{UZDROWISKA KARPACKIE W DOBIE TRANSFORMACJI}

Zarys treści: Omówiono czynniki wplywające na współczesna sytuację ekonomiczno-społeczną uzdrowisk. Z formalnego punktu widzenia można je podzielić na prawno-polityczne, ekonomiczne i spoleczne. $\mathrm{Na}$ podstawie przedstawionych uwarunkowań należy wnioskować, że mimo upływu czasu sytuacja uzdrowisk nie wykazuje symptomów znaczącej poprawy. Podjęto zatem próbę zaprezentowania działań uprawdopodobniających osiagnięcie pozytywnych wyników ekonomicznych i konkurencyjnej pozycji.

Słowa kluczowe: uzdrowisko, przedsiębiorstwo uzdrowiskowe, transformacja gospodarcza, turystyka uzdrowiskowa, obszar problemowy, Karpaty.

Wymuszona transformacją gospodarczo-ustrojową modernizacja i przystosowanie gospodarki do zasad rynkowych objęło również uzdrowiska, postrzegane zarówno jako przedsiębiorstwa, podmioty ochrony zdrowia i usług medycznych, gospodarki przestrzennej, jak również obszary recepcyjne ruchu turystycznego. Borykaja się one współcześnie $\mathrm{z}$ wieloma problemami; by przetrwać i zaistnieć w nowej rzeczywistości muszą podjać wysilek przekształcenia i adaptacji. Artykuł oparto zasadniczo na problemach przedsiębiorstw uzdrowiskowych.

Obszary koncentracji uzdrowisk można, zgodnie $\mathrm{z}$ założeniami strategicznego planowania przestrzennego, traktować jako obszary problemowe, tj. obszary koncentracji niekorzystnych zjawisk i procesów społeczno-gospodarczych. W odniesieniu do nich Unia Europejska sformułowała wytyczne polityki regionalnej uznające tereny cechujące się niskim poziomem rozwoju gospodarczego, występowaniem negatywnych skutków społecznych procesu przemian i wykazujące słabą dyna-

\section{CARPATHIAN SPAS DURING THE TRANSFORMATION PERIOD}

Abstract: The author discusses factors affecting the present economic and social situation of spas. Formally, they could be divided into statutory, economic and social. Based on the situation presented here it can be concluded that despite the passage of time the condition of spas has not improved. Thus the author attempts to present ideas which might bring about positive results and raise competitiveness.

Key words: spa resort, spa enterprises, economic transformation, health tourism, problem area, Carpathians.

Modernization forced by the economic and political transformation, as well as the adjustment of the economy to market conditions, has affected spas which are perceived simultaneously as economic enterprises, health care institutions, and tourism reception areas. Currently they struggle with many problems and in order to survive in the new conditions, they have to make changes and adapt. The article deals mainly with the problems of spa enterprises.

Following the rules of strategic spatial planning, places where spas are concentrated can be treated as problem areas, i.e. areas where activities and socio-economic processes unfavourable to growth co-occur. According to EU regional policy, poorly developed areas where the negative social consequences of the transformation and insufficient dynamic development are found, are able 
mikę rozwoju za obszary predysponowane do ubiegania się o maksymalne wsparcie finansowe $z$ Funduszy Strukturalnych.

Zgodnie z obowiązującą Ustawq o lecznictwie uzdrowiskowym, uzdrowiskach i obszarach ochrony uzdrowiskowej oraz o gminach uzdrowiskowych mianem uzdrowiska określamy obszar, na terenie którego prowadzone jest lecznictwo uzdrowiskowe, wydzielony w celu wykorzystania i ochrony znajdujących się na jego obszarze naturalnych surowców leczniczych (Ustawa o lecznictwie uzdrowiskowym... 2005). Bardziej precyzyjna definicja (Polskiego Komitetu Normalizacyjnego) mówi, iż uzdrowiskiem jest obszar mający złoża naturalnych surowców leczniczych, dostęp do wody morskiej i klimat o właściwościach leczniczych (albo jeden z tych czynników) oraz zakłady i urządzenia lecznictwa uzdrowiskowego, jak również sprzyjające warunki środowiskowe i sanitarne, w którym prowadzone jest metodyczne leczenie określonych chorób oraz może być prowadzona działalność uzdrowiskowo-turystyczna (Uzdrowiska - terminologia... 2001). Nigdzie nie zdefiniowano pojęcia przedsiębiorstwa uzdrowiskowego - samodzielnej jednostki gospodarczej wyodrębnionej prawnie i ekonomicznie, celem której jest dzialalność przynosząca zysk. Określono jedynie pojęcie zakładu lecznictwa uzdrowiskowego, który to termin nie jest tożsamy $z$ przedsiębiorstwem. Brak rozróżnienia uzdrowiska (w sensie przestrzennym) od przedsiębiorstwa uzdrowiskowego prowadzącego na wyodrębnionym obszarze działalność gospodarczą skutkuje poważnymi problemami w interpretacji zagadnień uzdrowiskowych.

Lista problemów okresu transformacji w uzdrowiskach jest długa, aczkolwiek można wyróżnić kilkanaście zagadnień krytycznych. Dla uzdrowisk rozumianych jako obszary (ujęcie przestrzenne), najbardziej naglącymi kwestiami wydają się być: bezrobocie, odplyw ludności i jej niskie dochody oraz ograniczenia planistyczne jakościowego i ilościowego rozwoju przestrzennego. Przedsiębiorstwa uzdrowiskowe borykają się $\mathrm{z}$ przemianami formy własności i zasad opodatkowania, złą kondycją finansowo-ekonomiczna, zmniejszeniem nakładów budżetu państwa, koniecznością wprowadzenia rynkowych zasad działania oraz przełamania monopolistycznej pozycji Narodowego Funduszu Zdrowia w dziedzinie dystrybucji i sprzedaży ich oferty. Na styku wymienionych sfer do rangi problemu urastaja kolejne zagadnienia - konieczność koegzystencji przedsiębiorstw i gmin uzdrowiskowych, niespójność, często sprzeczność i nie- to receive maximum financial support from the Structural Funds.

The operative Spa therapy, spa resort, spa protection area and spa gmina Act states that a spa is a place where spa therapy is practiced, established in order to exploit and protect its natural therapeutic resources (Spa therapy ... Act, 2005). A more precise definition provided by the Polish Normalization Committee (Polski Komitet Normalizacyjny) states that a spa is an area which possesses natural therapeutic resources, access to sea water or a climate with therapeutic properties, as well as an appropriate infrastructure, facilities and favourable environmental and sanitary conditions in which regular treatment of certain diseases can be conducted and spa tourism activity can be developed (Spas-terminology... 2001). The notion of a spa enterprise - a legally and economically independent unit whose aim is to run a profit-making activity - has not been defined. Only the notion of a spa therapy establishment has been described, but it is not identifiable with an enterprise. The lack of differentiation between a spa (in the spatial sense) and a moneymaking spa enterprise in a given area results in serious problems regarding the interpretation of spa issues.

The list of transformation period problems found in spas is long, but there are several which are critical. For spas understood spatially, the most urgent problems seem to be the following: unemployment, outflow of population, low income, as well as limitations affecting the extent and quality of spatial development. Spa enterprises are struggling with changes in the forms of ownership and the tax system, their own poor financial and economic condition, reduced state support, the necessity of introducing market economy principles and with the monopolist position of the Narodowy Fundusz Zdrowia (NFZ) as regards the distribution and sale of their offer. Other problems follow: the inevitable co-existence of spa enterprises and gminas, inconsistency, the frequent 
adekwatność przepisów prawnych dotyczących obszarów uzdrowiskowych, a także zagadnienie turystyki uzdrowiskowej.

\section{ZATRUDNIENIE I KWESTIA BEZROBOCIA}

Monokulturowość zatrudnienia w uzdrowiskach jest spuścizną poprzedniego systemu polityczno-ekonomicznego. W pewnym sensie wymusza ja prawo, ograniczając możliwość lokalizacji określonych dziedzin działalności gospodarczej w uzdrowiskach i ich najbliższym otoczeniu, ze względu na niekorzystne oddziaływanie na warunki naturalne. Ograniczenia różnicuje się ze względu na rodzaj obszaru ochrony uzdrowiskowej ${ }^{1}$, i tak do działalności niedozwolonych w obszarze $\mathrm{A}^{2}$ należy m.in. wprowadzanie zmian w zagospodarowaniu terenu, prowadzenie działalności rolniczej, hodowlanej, organizacja imprez masowych, lokalizacja nowych obiektów, zakładów i obiektów usługowych np. parkingów, targowisk. Na obszarze $\mathrm{B}^{3}$ zabronione jest lokalizowanie wielkopowierzchniowych obiektów handlowych, stacji paliw, urządzeń emitujących fale elektromagnetyczne itd., a w dalszej kolejności również zakładów przemysłowych, sztucznych zbiorników wodnych i regulacja rzek (w obszarze $\mathrm{C}^{4}$ ).

Generalnie, gospodarczo uzdrowiska są monolub dwufunkcyjne, co pociaga za sobą podatność na dekoniunkturę gospodarcza, upodobania klientów, zmiany polityki zdrowotnej państwa i jednocześnie uniemożliwia szybkie reagowanie czy przeprofilowanie (ze względu na specyfikę dzialalności).

W skali gospodarki narodowej zatrudnienie w sektorze uzdrowisk nie ma istotnego znaczenia. W całej Polsce usługi uzdrowiskowe zatrudniaja ok. 30 tys. osób, natomiast usługi im towarzyszące trzykrotnie więcej (ponad 100 tys. zatrudnionych) - udział zatrudnionych w lecznictwie uzdrowiskowym w stosunku do liczby osób aktywnych zawodowo wynosi 0,08\% (1999) (Informacja o wynikach kontroli... 2002). Należy jednak zwrócić uwagę na znaczące efekty mnożnikowe. Doświadczenia krajów europejskich pokazują, że jedno miejsce pracy utworzone w turystyce pociaga za sobą 3-5 nowych miejsc pracy w ushugach towarzyszących, natomiast jedno miejsce pracy w lecznictwie uzdrowiskowym generuje aż 7 miejsc pracy w usługach pokrewnych (GOLBA 2002). contradictions and inadequacy of legal regulations concerning spa areas, as well as the issue of spa tourism.

\section{EMPLOYMENT POLICY}

The single employment situation in spas has been inherited from the former political and economic system. In a sense it is imposed by the law which limits the locating of certain economic activities in spas and their immediate neighbourhood for environmental reasons. The limitations can be divided into groups according to the type of the protected area ${ }^{1}$. In area $\mathrm{A}^{2}$ it is forbidden to change the infrastructure, cultivate land, rear animals, organize mass events, or erect new buildings and service facilities, e.g. car parks, open-air markets, etc. In area $\mathrm{B}^{3}$ it is forbidden to open supermarkets, petrol stations, install devices emitting electromagnetic waves, etc., as well as factories, artificial water reservoirs and river regulating devices (area $\mathrm{C}^{4}$ ).

Generally speaking, from an economic point of view, spas are mono- or bifunctional, which results in their susceptibility to economic recession, client preferences, changes in state health policy, and at the same time it makes it impossible to react quickly to change and to alter their current profile (due to the special character of the activity).

On a national scale, employment in the spa sector is rather insignificant. It amounts to 30000 in Poland, and in related services three times that number (over 100 000). The percentage employed in spa therapy in relation to all working people is 0.08\% (1999) (Informacja o wynikach kontroli... 2002). However, considerable multiplier effects should be noticed. From the experience of European countries, one new job in tourism generates 3-5 new jobs in related services, and one new job in spa therapy generates seven jobs in related services (GOLBA 2002). 
Kryzys lecznictwa uzdrowiskowego doprowadził do znacznych cięć w zatrudnieniu - średnio o około 11\% (w latach 1998-2001), maksymalnie w latach 1998-1999, gdy cięcia w poszczególnych spólkach wahały się od $15,6 \%$ do aż $51,0 \%$ (WolOWIEC 2003a) (rys. 1). W poszczególnych uzdrowiskach bezrobocie waha się od 16 (Krynica) do 36\% (Jedlina) (HANDZEL 2001), w uzdrowiskach Małopolski zatrudnienie spadło o $33 \%$ $(1999=100 \%)$. Spółki uzdrowiskowe zmuszone są restrukturyzować zatrudnienia poprzez jego redukcję, ale też szkolenia i podnoszenie kwalifikacji personelu. Ograniczenie zatrudnienia z reguły prowadzi do minimalizacji kosztów działalności (Szczawnica), ale nie zawsze do jej urentownienia (Wysowa) (Informacja ... 2002). Jedyny w Karpatach przypadek zwiększenia zatrudnienia dotyczy uzdrowiska Ustroń, gdzie liczba pracowników wzrosła o 4,5\% (1999-2001).

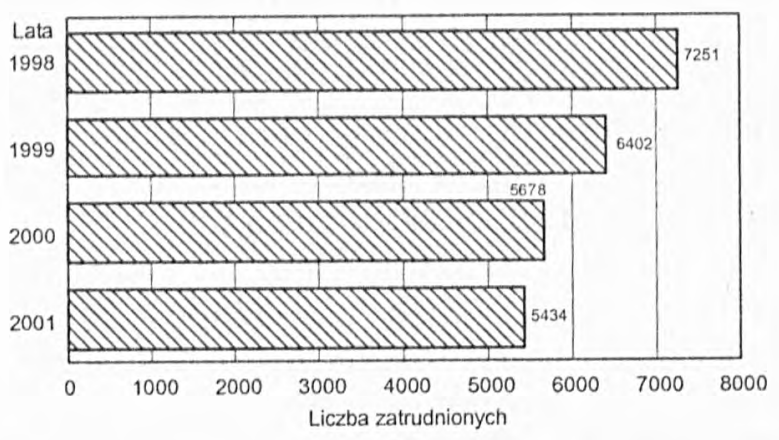

Rys. 1. Zatrudnienie w karpackich przedsiębiorstwach uzdrowiskowych w latach 1998-2001 - w liczbach bezwzględnych (żród ło: WOLOWIEC 2003)

\section{PRZEMIANY FORM WEASNOŚCI}

Przed II wojną światową uzdrowiska w większości stanowiły dobra prywatne: osób fizycznych, towarzystw lekarskich lub instytucji ubezpieczeniowych. Istniało także sześć uzdrowisk państwowych (Burkut, Busko, Ciechocinek, Druskienniki, Krynica i Szkło), pięć komunalnych (m.in. Otwock i Piwniczna) i dwa kurorty o statusie dóbr publicznych (Zakopane i Zaleszczyki). W roku 1948 z przymusowo znacjonalizowanego majątku wszystkich polskich kurortów utworzono 26 oddzialów Państwowych Przedsiębiorstw Uzdrowiskowych. Podstawa prawną operacji byla ustawa nacjonalizacyjna z 1946 r. mówiąca o przedsiębiorstwach
The crisis in spa therapy has led to significant cuts in employment, by $11 \%$ on average (1998-2001). They were the biggest in 1998-1999 and were between 15.6 and $51.0 \%$ in individual enterprises (Wolowiec 2003) (fig. 1) while in individual spas unemployment ranges from $16 \%$ (Krynica) to 36\% (Jedlina) (HANDzEL 2001). In the spas of Małopolska alone employment has dropped by 33\% (1999 $100 \%)$. Spa enterprises are forced to restructure employment by reducing it, but also by running courses and raising the qualifications of their personnel. Reducing employment usually leads to reduced costs (Szczawnica), but not always to larger profits (Wysowa) (Informacja o ... 2002). A case of increasing employment was noted in Ustron, the only one in the Carpathians where the number of workers grew (by 4.5\% 1999-2001).

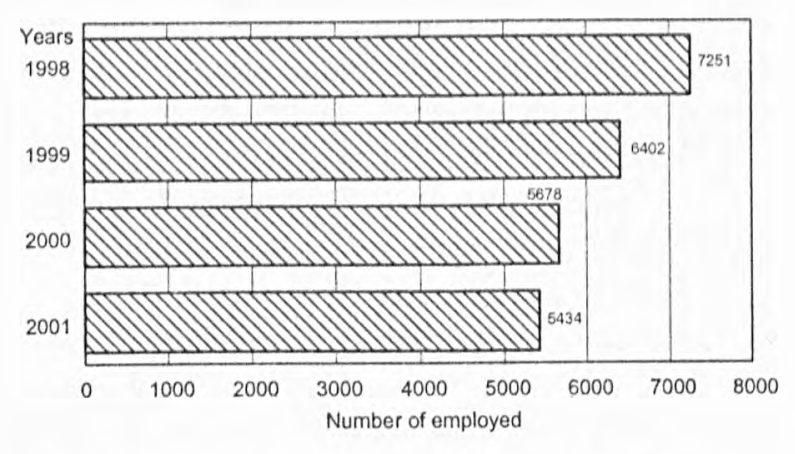

Fig. 1. Employment in Carpathian spa enterprises in 1998-2001 (absolute figures) (s o u r c e: WOLOWIEC 2003)

\section{CHANGING FORMS OF OWNERSHIP}

Before World War II the majority of spas were private property belonging to individual owners, medical societies or insurance companies. There were also six state spas (Burkut, Busko, Ciechocinek, Druskienniki, Krynica and Szkło), five local authority ones (e.g. Otwock and Piwniczna) and two resorts with special public status (Zakopane and Zaleszczyki). In 1948 all Polish spas were nationalized and 26 State Spa Enterprises were created. This move followed the Nationalization Act of 1946 regarding enterprises 
produkcyjnych ważnej gałęzi gospodarki narodowej.

Transformacja prawno-polityczna umożliwiła spadkobiercom wlaścicieli kurortów rozpoczęcie starań o zwrot majątku (działania reprywatyzacyjne). Po roku 1990 roszczenia takie zgloszono względem dziewięciu spółek, m.in. Uzdrowiska Krynica-Żegiestów SA, Rabka SA, Rymanów SA, Iwonicz SA, Szczawnica SA i Wysowa SA. Zostaty one zaspokojone jedynie w przypadku uzdrowiska Solec.

W latach 1996-1997 w proces przemian własnościowych włączyly się samorządy terytorialne. Komunalizacją majątku uzdrowisk zainteresowane były m.in. Szczawnica i Krynica. W jednym przypadku - uzdrowiska Wapienne (obecnie w gestii gminy Sękowa) - udało się działania te doprowadzić do końca.

Na przełomie lat 1998/1999 dokonano komercjalizacji Państwowych Przedsiębiorstw Uzdrowiskowych, w wyniku czego powstały jednoosobowe spółki Skarbu Państwa (17 spółek akcyjnych i 9 spółek z o.o.). Komercjalizacja była pierwszym etapem prywatyzacji pośredniej (kapitałowej). Wlaściwe działania prywatyzacyjne rozpoczęto w roku 2001, jednakże dotychczas sprywatyzowano zaledwie jedno przedsiębiorstwo (Uzdrowisko Nałęczów SA), którego inwestorem strategicznym została holenderska firma East Spring International (część międzynarodowego koncernu spożywczego Nestlé). Roszczenia reprywatyzacyjne doprowadzily do zaniechania prywatyzacji drugiego najbardziej zaawansowanego $\mathrm{w}$ tym procesie uzdrowiska - Iwonicza. W pozostałych spólkach procesy prywatyzacyjne wstrzymano do momentu uchwalenia nowej ustawy uzdrowiskowej. Jednocześnie tworzono nowatorski projekt inicjujący nową kategorię uzdrowisk, tzw. uzdrowiska narodowe, które planuje się wyłączyć z prywatyzacji, a następnie ukierunkować na lecznictwo uzdrowiskowe i rehabilitację.

W styczniu 2004 r., po nieudanej próbie uchwalenia nowej ustawy uzdrowiskowej, Ministerstwo Skarbu podzieliło polskie uzdrowiska na cztery grupy. W pierwszej znalazły się przedsiębiorstwa przeznaczone do prywatyzacji, w drugiej spółki wymagające indywidualnego podejścia $\mathrm{w}$ procesie prywatyzacji ze względu na unikalne zasoby naturalne, trzecią tworzą uzdrowiska narodowe. Do ostatniej grupy zakwalifikowano spółki w trakcie procesów reprywatyzacyjnych w zaawansowanym stadium. Ciekawe spostrzeżenia daje porównanie wyników finansowych uzdrowisk of important branches of the national economy.

The legislative and political transformation enabled the heirs of the resort owners to claim their property back (reprivatisation). After 1990 such claims were submitted for nine enterprises, e.g. Krynica-Żegiestow S.A., Rabka S.A., Rymanów S.A., Iwonicz S.A., Szczawnica S.A. and Wysowa S.A. However, only one of them was settled (Solec).

In 1996-1997 local authorities became involved in the process of ownership transformations and Szczawnica and Krynica were interested in taking over spa property ('communalisation'). In one case, that of Wapienne spa (currently belonging to the gmina of Sepkowa), the process was successfully completed.

At the turn of 1999 the State Spa Enterprises were 'commercialised', which resulted in finance ministry enterprises (17 joint-stock and 9 limited liability enterprises). Commercialisation was the first step towards indirect (capital) privatisation. The actual privatisation was initiated in 2001, however so far only one enterprise has been privatised (Nałęczów S.A.) whose strategic investor was a Dutch firm, East Spring International (part of the Nestle international food concern). In the case of Iwonicz, the second most advanced spa as far as reprivatisation is concerned, the demands were too high and the procedure was abandoned. In the remaining enterprises privatisation processes have been suspended until a new spa act is passed. At the same time a new project was designed which introduced a new category i.e. National Spas, intended to be excluded from privatisation and, following that, oriented towards spa therapy and rehabilitation.

In January 2004, after a failed attempt to pass a new spa act, the Ministry of Finance divided Polish spas into four groups. The first included enterprises intended for privatisation, the second enterprises requiring an individual approach in the process of privatisation due to their unique natural resources, the third consists of national spas while the last includes enterprises at an advanced stage 
sklasyfikowanych w poszczególnych grupach (tab. I). W grupie I znajdują się przedsiębiorstwa wykazujące znaczne straty finansowe. Na przeciwległym końcu (grupa III) umiejscowiono spólki przynoszące największe zyski. Resort Skarbu preliminowal zatem do prywatyzacji przedsiębiorstwa, których szanse znalezienia inwestora strategicznego są znikome, zaś spółki, których prawdopodobieństwo sprzedaży jest znaczne, wyłączono $\mathrm{z}$ prywatyzacji, zamykając tym samym drogę ich rozwoju. of privatisation. It is interesting to compare the profits made by spas from individual groups (table I). Spas from group I make considerable financial losses while at the other extreme in group III there are enterprises which make the highest profits. The finance ministry selected those enterprises to be privatised whose chances of finding strategic investors were slim, while those which were likely to be sold were excluded from privatisation which terminated their prospects for development.

T a b e I a I. Najnowszy plan prywatyzacji a wynik finansowy spółek uzdrowiskowych (dane na koniec września 2003)

T a b | e I. The latest privatisation plan and the profits made by spa enterprises (end of September 2003)

\begin{tabular}{|c|c|c|}
\hline Grupa & Uzdrowisko & $\begin{array}{l}\text { Wynik finansowy } \\
\text { (w tys. zł) }\end{array}$ \\
\hline Group & Spa & $\begin{array}{c}\text { Profit } \\
\text { (in thousands of PLN/zlotys) }\end{array}$ \\
\hline \multirow{5}{*}{1} & Zespół Uzdrowisk Krakowskich & +39 \\
\hline & Przerzeczyn & -104 \\
\hline & Kamień Pomorski & -271 \\
\hline & Konstancin & -437 \\
\hline & Wieniec & -1106 \\
\hline \multirow{7}{*}{$\|$} & Połczynl & -86 \\
\hline & Cieplice & +56 \\
\hline & Horyniec & +56 \\
\hline & Ustka & +67 \\
\hline & Swieradów-Czerniawa & +161 \\
\hline & Wysowa & +400 \\
\hline & Inowroctaw & +404 \\
\hline \multirow{10}{*}{ III } & Krynica-Żegiestów & -740 \\
\hline & Kotobrzeg & +57 \\
\hline & Swinoujscie & +163 \\
\hline & Szczawno-Jedlina & +316 \\
\hline & Busko & +646 \\
\hline & Ladek Długopole & +648 \\
\hline & Rymanów & +921 \\
\hline & Ciechocinek & +1110 \\
\hline & Ustrón & +1673 \\
\hline & Zespół Uzdrowisk Kłodzkich & +3524 \\
\hline \multirow{3}{*}{ IV } & Szczawnica & -927 \\
\hline & Rabka & -474 \\
\hline & Iwonicz & +105 \\
\hline
\end{tabular}

1 - przewidziane na sprzedaż, II - akcje albo udziały w gestii państwa (min. 5 lat), III - wyłączone z prywatyzacji (uzdrowiska narodowe), IV - prywatyzacja odroczona z powodu roszczeń reprywatyzacyjnych.

I - likely to sell, II - state shares or bonds (min. 5 years), III - excluded from privatisation (National Spas), IV - enterprises at an advanced stage of privatisation.

Żródło/S o u r ce: PRZYBYLSKI (2004)

Najczęściej poruszanym zagadnieniem dotyczącym prywatyzacji jest konieczność ochrony zasobów naturalnych i możliwości leczniczych. Uzdrowiska obawiają się rezygnacji inwestorów z prowadzenia działalności leczniczej na rzecz bardziej dochodowej turystyki lub koncentracji
The most frequently discussed privatisation problem is the necessity of protecting natural resources and 'therapeutic capacity'. The spas are afraid that investors might abandon therapeutic activity and turn to more profitable 
wysiłków na wydobyciu i eksploatacji wód mineralnych. Rozwiązaniem sugerowanym jest zastrzeżenie w umowach, że kopaliny (np. wody mineralne, borowiny) nie podlegają prywatyzacji oraz zaklasyfikowanie zasobów leczniczych jako wlasności Skarbu Państwa i poddanie ich rygorom identycznym jak przy wydobyciu innych kopalin - czyli koncesjonowaniu.

\section{KONDYCJA FINANSOWO-EKONOMICZNA SPÓEEK UZDROWISKOWYCH}

Niekorzystna sytuacja finansowo-ekonomiczna przedsiębiorstw uzdrowiskowych jest w dużej mierze od nich niezależna, a wynika z obniżenia nakładów na lecznictwo uzdrowiskowe, strategii Narodowego Funduszu Zdrowia, wzrostu poziomu należności oraz spadku płynności finansowej spowodowanej nieterminową regulacją zobowiązań przez kontrahentów (głównie przez NFZ), konieczności wykonywania zadań na rzecz lokalnej spoleczności oraz finansowania inwestycji rozpoczętych przed rokiem 1999 i wzrostu stawek podatkowych.

W pierwszym okresie funkcjonowania gospodarki wolnorynkowej (1990-1997) nakłady na ochronę zdrowia malaty, aczkolwiek nieznacznie i stopniowo (lecznictwo uzdrowiskowe utraciło blisko $20 \%$ funduszy). Jeszcze w latach 1997 i 1998 przeznaczano na nie $383 \mathrm{mln} z l$ (w przeliczeniu 4,0-4,5\% obecnego budżetu NFZ) (GOLBA 2002). Drastyczny spadek nakładów zaznacza się od roku 1999 - do $1,45 \%$ (od $0,81 \%$ do $2,34 \%$ ) środków finansowych będących w dyspozycji NFZ, wynikiem czego był $20 \%$ spadek liczby zakontraktowanych osobodni, przy jednoczesnym wzroście liczby ubezpieczonych oczekujących na realizacje skierowań. Wymuszony spadek sprzedaży usług dla NFZ wyniósł od 72 do $60 \%$ (w okresie 1999-2001), przy jednoczesnym ponad dwukrotnym wzroście udziału ZUS (do 20\%). Ustabilizowala się wielkość rynku pacjentów pełnoplatnych (ok. 15\%), wzrósł rynek pacjentów z doplatami NFZ (z 6 do 8\%) (WOŁOWIEC 2003b). Sytuacja się pogarszała - w roku 2000 nakłady stanowiły już jedynie 82,5\% funduszy z roku 1998 . Pomimo faktu, że w 2001 r. budżet NFZ wzrósl o 33,7\% (w porównaniu do 1999 r.), realne nakłady na kontrakty uzdrowiskowe zmniejszyły się o 2,2\%. $\mathrm{Z}$ raportu NIK wynika, że zmniejszenie liczby kontraktowanych miejsc powiększylo o $30,7 \%$ grupe osób oczekujących na realizację swoich skierowań. W 2001 r. popyt na lecznictwo uzdrowiskowe był tourism or to focus on the exploitation of mineral waters. The suggested solution is to include a clause in the contracts stating that mineral resources (e.g. mineral waters and therapeutic mud), are not subject to privatisation, and to classify therapeutic resources as state property and licence them.

\section{THE FINANCIAL AND ECONOMIC SITUATION OF SPA ENTERPRISES}

The unfavourable financial and economic situation of spa enterprises has largely resulted from lower expenditure on spa therapy, the strategy of the Narodowy Fundusz Zdrowia (NFZ), growing debts and decreasing financial liquidity caused by overdue payments from partners (mainly the NFZ), the necessity to work for the local community and to subsidize investments started before 1999 and, finally, from growing tax rates.

At the first stage of the free market economy (1990-1997), however insignificantly and slowly, expenditure on health care decreased (spa therapy lost nearly 20\% of its funds). In 1997 and 1998 it was given 383 million zlotys (4.0-4.5\% of the current NFZ budget) (GolbA 2002). A drastic decrease in expenditure has been observed since 1999 - down to $1.45 \% \quad(0.81 \%-2.34 \%)$ of NFZ funds, which has resulted in smaller contracts and a larger number of insured patients waiting for their turn for treatment. The decreased sales of services to the NFZ have been reduced to $72 \%-60 \%(1999-2001)$ and at the same time the share of the ZUS (Social Insurance) doubled (to 20\%). The market for full-price patients has stabilized (c. $15 \%$ ) and that of patients with $\mathrm{NFZ}$ subsidies increased (from 6\% to 8\%) (WolowIEC 2003). The situation was deteriorating. In 2000 the expenditure reached only $82.5 \%$ of that in 1998. Despite the fact that in 2001 the NFZ budget was increased by $33.7 \%$ (compared to 1999), the actual 
zaspokajany przeciętnie na poziomie $66 \%$, przy czym aż $w$ trzech regionalnych oddziałach NFZ okres oczekiwania przekraczal dwa lata.

Powyższa analiza dowodzi, że do kłopotów finansowych uzdrowisk przyczynił się niekorzystny budżet kraju, jak również NFZ. Problem nie leży jedynie w wielkości nakładów finansowych, ale również w polityce funduszu względem przedsiębiorstw świadczących usługi medyczne. Strategia ta opiera się na indywidualnej polityce każdego oddziału regionalnego, zmuszającej firmy (szpitale, przedsiębiorstwa uzdrowiskowe oddziały ratownictwa medycznego) do prowadzenia osobnych negocjacji z każdym z tych oddziałów i podporządkowania się niejednolitym standardom kontraktowania i rozliczania usług. Fakt, że wszystkie kontrakty są jednoroczne, bez możliwości zapewnienia kontynuacji działań w wynegocjowanym wymiarze i formie, uniemożliwia przedsiębiorstwom zarządzanie strategiczne. Nie sposób opierać planów dhugookresowych firmy na nieprzewidywalnych przesłankach działalności NFZ, który w większości przypadków jest głównym kontrahentem. Na dzień dzisiejszy niewyplacalność znacznej części przedsiębiorstw uzdrowiskowych, ich zadłużenie i realna groźba utraty płynności finansowej spowodowana jest nieterminowym regulowaniem zobowiązań przez kontrahentów, głównie przez NFZ.

Pochodząca z 1966 r. i obowiązująca do 1 X 2005 r. ustawa o uzdrowiskach i lecznictwie uzdrowiskowym była w ogromnym stopniu zdezaktualizowana. Większość jej przepisów pozostawała w sprzeczności z wprowadzonymi po 1989 r. aktami prawnymi regulującymi funkcjonowanie instytucji i obszarów związanych z uzdrowiskami. Najwięcej rozbieżności wykazywała w porównaniu $\mathrm{z}$ ustawami: o samorządzie terytorialnym, planowaniu i zagospodarowaniu przestrzennym, podatkach i opłatach lokalnych, ochronie środowiska, lasach, z prawem wodnym, prawem geologicznym i górniczym, a także z konstytucją i przepisami reformy administracyjnej. Przykładem takiej antynomii był nałożony na przedsiębiorstwa uzdrowiskowe (jako dysponujące majątkiem uzdrowiska) obowiązek wykonywania zadań na rzecz lokalnej społeczności, np. utrzymywania infrastruktury istniejącej na terenie miejscowości uzdrowiskowej, chociaż niezwiązanej bezpośrednio z usługami leczniczymi. Reorganizacja własności uzdrowisk, która doszła do skutku w 1999 r., spowodowała konieczność finansowania inwestycji rozpoczętych wcześniej, zaaprobowanych wówczas przez państwo jako ówczesnego gestora. Obecna kondycja finansowa uzdrowisk jest expenditure on spa contracts decreased by $2.2 \%$. The NIK reports say that the decreased number of contracted places had increased the waiting list of patients by $30.7 \%$. In 2001 only $66 \%$ on average of the demand for spa therapy was met, and in three regional NFZ sections the waiting period exceeded two years.

This analysis shows that the spas' financial problems were caused by an unfavourable state budget and the NFZ. The problem lies not only in the size of the expenditure, but also in the NFZ's policy towards medical service enterprises based on the individual strategy of each regional section, forcing firms (hospitals, spa enterprises and emergency rescue sections) to negotiate with each individually and submit to varying standards of contracting and calculating services. The fact that all contracts are drawn up for one year and there is no opportunity to ensure their continuation in the same form, makes strategic management impossible. Long-term planning cannot be based on unpredictable moves by the main partner the NFZ. As for today, the indebtedness of the majority of spa enterprises and the real danger of insolvency, are caused by overdue payments from partners, mainly the NFZ.

The Spa Resort and Spa Therapy Act, which was in force from 1996 to $1^{\text {st }}$ October 2005, was very much out of date. Most of its regulations contradicted the laws regulating the functioning of spa institutions and areas passed after 1989. Most discrepancies were observable when compared with laws concerning local government, spatial planning and infrastructure, taxes and local charges, environmental protection and forests. There were also considerable differences as regards water laws, geological and mining laws, as well as the constitution and administration reform regulations.

A large number of the most urgent problems were settled by the new Spa therapy, spa resort, spa protection area 
po części spuścizną uprzedniego właściciela: Skarbu Państwa.

Dużą część najpilniejszych kwestii uregulowano ostatecznie w uchwalonej w 2005 r. nowej Ustawie o lecznictwie uzdrowiskowym, uzdrowiskach $i$ obszarach ochrony uzdrowiskowej oraz o gminach uzdrowiskowych, jednakże nawet ona nie wyczerpuje złożonej problematyki. Środowiska uzdrowiskowe pracują obecnie nad koncepcją dodatkowego aktu prawnego odnoszącego się do specjalnych zasad funkcjonowania samych tylko gmin uzdrowiskowych.

Ważnym aspektem kondycji ekonomiczno-finansowej uzdrowisk są systematycznie wprowadzane zmiany zasad opodatkowania. Największe obciążenia fiskalne wiążą się z podatkiem VAT, podatkiem od nieruchomości, taksa uzdrowiskowa oraz opłatami za korzystanie ze środowiska. Uzdrowiska traktowane są jak przedsiębiorstwa produkcyjne w zakresie wszystkich podatków oprócz VAT, gdzie lecznictwo uzdrowiskowe zaliczono do działalności zwolnionej z podatku, w wyniku czego firmy nie mogą odliczyć różnicy między należnym a naliczonym podatkiem VAT, a w rezultacie odzyskać nadwyżki (GOLBA 2002). Takie odliczenie byłoby możliwe przy wprowadzeniu zerowej stawki podatku. Ponadto w ogólnie przyjętym rozporządzeniu stawka podatku VAT dla leków wynosi 7\%, mimo to produkcja i sprzedaż wód leczniczych, zakwalifikowanych jako leki, obciążona jest wyższa, 22\% stawką VAT (KIDOŃ 2002).

Stawki podatku od nieruchomości są zróżnicowane w zależności od typu użytkowania: nieruchomości służące np. celom mieszkaniowym obowiązują stawki niższe, zaś budynki wykorzystywane do prowadzenia działalności gospodarczej stawki wyższe. Do roku 1999 wszystkie zakłady opieki zdrowotnej obowiązywała stawka niższa (30\% stawki bazowej) do której byly uprawnione jako przedsiębiorstwa użyteczności publicznej (WolowIEC 2002). Po komercjalizacji przepisy zinterpretowano na nowo - uzdrowiska zaczęły obowiązywać stawki przeznaczone dla podmiotów prowadzących działalność gospodarczą, co oznaczało trzykrotny wzrost podatku w przeciagu zaledwie dwóch lat. Zabieg ten, poprawny z punktu widzenia zasady równości gospodarczej, budzi obiekcje ze względu na sposób jego wprowadzenia.

Pozostałe podatki ściśle wiąża się z samorządem terytorialnym, zobligowanym do ich egzekwowania. Jest to taksa uzdrowiskowa, $\mathrm{tj}$. oplata za oferowane i wykorzystywane przez przyjezdnych urządzenia gminy, której płatnikami są turyści, kuracjusze i in- and spa gmina Act from 2005, but even the new legislation does not solve all of them. An additional law is being drawn up which refers to special principles for the functioning of spa gminas.

The regular changes in the tax system are an important aspect of the economic and financial conditions of spas. The largest sums include VAT, property tax, spa tax and an environmental charge. Spas are treated as production enterprises as regards all taxes, except VAT where spa therapy is exempt. As a result, firms cannot deduct the difference between VAT which is due and that which has been calculated, and retrieve the overpaid sum (GOLBA 2002). Such a deduction would be possible if a zero tax rate were introduced. Besides, according to general regulations, the VAT on medicines is $7 \%$, while for the production and sale of therapeutic waters, qualifying as medicine, it is 22\% (KIDON 2002).

Property tax rates vary depending on how the property is used. For residential buildings they are lower, while for those used for economic activity they are higher. Before 1999 all therapeutic enterprises had paid lower rates (30\% of the base rate), and had been treated as public use enterprises (Wolowiec 2002). After the commercialisation regulations were re-interpreted, spas started to pay taxes similar to those paid by firms running economic activity, which meant a three-fold increase in tax just over two years. This move, though appropriate from the point of view of economic equality, raised doubts because of the way it was done.

The remaining taxes are strictly connected with local government which is obliged to claim them. The spa tax is the charge paid by tourists, patients and others who are not permanent residents of a gmina for its facilities (e.g. owners of second houses). It was first introduced in Poland in 1922 along with the first spa act, was in force for 70 years and in 1992 was abolished. After local government 
ne osoby przebywające w gminie, a niebędące stałymi mieszkańcami (np. posiadacze drugich domów). W Polsce po raz pierwszy wprowadzono ją w roku 1922 - równocześnie z I ustawą o uzdrowiskach. Obowiązywala przez 70 lat; w 1992 r. zabroniono jej pobierania. Po interwencjach samorządów lokalnych przywrócono na bardzo niskim, nieadekwatnym do potrzeb poziomie. Drugą opłatą są kary z tytułu szkód wyrządzonych w środowisku naturalnym (np. przedwczesnego wylesiania terenu). Instytucją odpowiedzialną za nadzór jest również gmina, która $\mathrm{w}$ związku $\mathrm{z}$ tym ponosi określone koszty. Niemniej jednak wszystkie środki pieniężne z tytułu powyższych kar przekazywane są do Centralnego Funduszu Ochrony Przyrody, a w efekcie prawie nigdy nie trafiają do miejsca, gdzie zostały wygospodarowane, by służyć niwelowaniu wyrządzonych szkód. Samorządy terytorialne postulują przeznaczenie tych opłat na gminny fundusz ochrony środowiska (JaGUSIEWICZ 2002). Poruszone wyżej zagadnienia podatkowe są ilustracją problemów wspólistnienia przedsiębiorstw i gmin uzdrowiskowych, powodowanych najczęściej nieścisłościami w przepisach prawnych nakladających na gminy szereg obowiązków, nie precyzując źródeł finansowania dodatkowych zadań. Gminy zmuszone są wykonywać nadprogramowe zadania ze środków przewidzianych na zaspokojenie potrzeb własnych mieszkańców, co jest sprzeczne $\mathrm{z}$ ustawą o samorządzie gminnym i konstytucją.

\section{DYSTRYBUCJA I SPRZEDAŻ OFERTY UZDROWISK}

Sieć dystrybucji usług uzdrowisk obejmuje trzy kanały, tj. sprzedaż za pośrednictwem Narodowego Funduszu Zdrowia (NFZ), organizacji socjalnych (ZUS, PFRON, KRUS) oraz sprzedaż wolnorynkowa.

$\mathrm{Z}$ ramienia Narodowego Funduszu Zdrowia leczenie uzdrowiskowe przysługuje każdemu ubezpieczonemu w wymiarze $21 \mathrm{dni}$, raz na dwa lata. Bezplatny jest pobyt dzieci i mlodzieży (do lat 18) oraz dorosłych w szpitalu uzdrowiskowym, gdzie NFZ pokrywa koszty leczenia, wyżywienia i zakwaterowania. Częściową odpłatność za wyżywienie i zakwaterowanie ponosi kuracjusz przebywający w sanatorium uzdrowiskowym. Koszty dojazdu na leczenie zawsze pokrywa ubezpieczony.

Leczenie uzdrowiskowe w ramach tzw. prewencji rentowej ZUS dotyczy rehabilitacji osób zagro- intervention, it was reinstated at a very low rate, and inadequate to the need. Other payments are the fines for damage to the natural environment (e. g. premature deforestation of an area). The supervising institution is also the gmina which bears some costs. However, all the money obtained this way is directed to the Centralny Fundusz Ochrony Przyrody and hardly ever goes to the place where it was collected in order to repair the damage. Local governments suggest that these charges should be given to a gmina environmental protection fund (JAGUSZEWICZ 2002). The tax issues discussed above illustrate the problems of co-operation between spa enterprises and gminas, mostly caused by 'inaccuracies' of legislature; legal regulations impose a number of obligations on gminas without indicating potential financial sources. Gminas are forced to complete additional tasks using funds originally intended for satisfying their own residents' needs which contradicts the regulations of gmina government and the constitution.

\section{DISTRIBUTION AND SALE OF THE SPA OFFER}

The distribution network for the spa offer comprises three channels: sale via the $\mathrm{NFZ}$, social organizations (ZUS, PFRON, KRUS) and free-market sale.

As far as the NFZ is concerned, every insured person has a right to spa treatment for 21 days once in two years. Children, teenagers (under 18 years of age) and adults are entitled to a free stay in a spa hospital where the NFZ covers the costs of treatment and board. A patient who stays at the spa sanatorium partly covers the cost of food and accommodation him/herself. Travelling expenses are always covered by the insured person.

Spa treatment as part of the ZUS preventative medicine scheme, concerns the rehabilitation of those in danger of 
żonych calkowitą lub częściową niezdolnościa do pracy albo pobierających rentę okresowa, a rokujących odzyskanie zdolności do pracy zarobkowej. ZUS jest drugim po NFZ największym kontrahentem, któremu w 2001 r. sprzedano 19\% usług uzdrowiskowych. ZUS w całości pokrywa koszty procedur leczniczo-rehabilitacyjnych, wyżywienia i zakwaterowania oraz zwraca równowartość kosztów podróży. Współpracuje obecnie z 39 ogólnopolskimi ośrodkami rehabilitacyjnymi leczącymi schorzenia narządów ruchu, psychosomatyczne, układu krążenia i układu oddechowego. Dysponuje jednorazowo 4400 lóżkami w systemie stacjonarnym (rys. 2). Programem rehabilitacji leczniczej $w$ ramach prewencji rentowej ZUS objęto w latach 2001-2003 odpowiednio 59 946, 65 841, 64351 osób (Rehabilitacja rentowa... 2004). complete or partial inability to work or those who claim temporary sickness benefit but are likely to return to work. After the NFZ, ZUS is the biggest partner and in 2001 it sold $19 \%$ of all spa services. ZUS fully covers the costs of treatment and rehabilitation procedures, food and accommodation, as well as travel. It currently cooperates with 39 national rehabilitation centres where illnesses of the motor, blood circulation and respiratory systems, as well as psychosomatic diseases are treated. It offers 4,400 beds at a time (fig. 2). In 2001, 2002 and 2003 the rehabilitation programme, as part of the ZUS preventative medicine scheme, treated 59,946, 65,841 and 64,351 patients, respectively (Rehabilitacja rentowa... 2004).
Rys. 2. Struktura miejsc w obiektach rehabilitacji ZUS wg rodzaju schorzenia w 2004 r. (ż ró d to: Rehabilitacja rentowa... 2004)

1 - choroby narzadów ruchu; 2 - choroby układu krażenia; 3 - choroby układu oddechowego; 4 - schorzenia psychosomatyczne
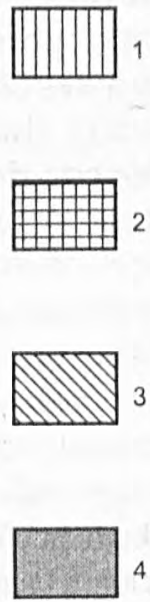

Fig. 2. Places in ZUS rehabilitation institutions according to the type of illness (2004) (s o u r c e: Rehabilitacja rentowa... 2004) 1 - motor system, 2 - blood circulation system, 3 - respiratory system, 4 psychosomatic illnesses
Kasy Rolniczego Ubezpieczenia Społecznego (KRUS) również prowadzą rehabilitację leczniczą rolników w niektórych uzdrowiskach. Inaczej niż ZUS, nie korzystają z sanatoriów i szpitali uzdrowiskowych należących do przedsiębiorstw uzdrowiskowych, lecz z własnych obiektów rehabilitacyjnych określanych mianem Centrów Rehabilitacji Rolników (CRR). 21-dniowy pobyt i leczenie jest bezpłatne, określone wewnętrznymi zasadami. Każdego roku z rehabilitacji za pośrednictwem KRUS korzysta ok. 14 tys. osób. Od utworzenia w 1992 r. pierwszego CRR w Iwoniczu, do końca 2002 r. skorzystało z niego 116 tys. osób (Rehabilitacja..., 2004). Współcześnie działa pięć Centrów Rehabilitacji Rolników: w Horyń-
KRUS (Kasa Rolnicza Ubezpieczenia Społecznego - agricultural worker's social insurance) covers the cost of rehabilitation in some spas. Unlike ZUS, it does not make use of sanatoria and spa hospitals which belong to spa enterprises, but uses its own rehabilitation facilities, described as Centra Rehabilitacji Rolników (CRR). A 21-day stay and treatment are free based on internal regulations. Each year about 14,000 patients undergo rehabilitation via KRUS. Between 1992, when the first CRR was opened in Iwonicz, and the end of $2002,116,000$ patients had benefited from it (Rehabilitacja... 2004). 
cu Zdroju, Iwoniczu Zdroju, Kolobrzegu, Jedlcu i Szklarskiej Porębie, posiadających łącznie ok. 1000 miejsc.

Państwowy Fundusz Rehabilitacji Osób Niepelnosprawnych (PFRON) nie posiada wlasnych obiektów rehabilitacyjnych w uzdrowiskach, lecz przyznaje dofinansowania na pobyty lecznicze i rehabilitacyjne. Subwencje dotyczą osób powyżej 16 roku życia, posiadających aktualne orzeczenie o stopniu inwalidztwa, niezdolności do pracy $\mathrm{w}$ rolnictwie lub objęte zasiłkiem pielęgnacyjnym. Subsydium waha się od 25 do $100 \%$ najniższego wynagrodzenia. Preferencyjnie traktowane sa osoby $\mathrm{w}$ trudnej sytuacji materialnej i w znacznym stopniu niepelnosprawne.

Wynikajace $\mathrm{z}$ reformy służby zdrowia zmiany zasad refundowania pobytów sanatoryjnych pociągnęły za sobą spadek liczby kuracjuszy. W celu zapelnienia wolnych miejsc spólki uzdrowiskowe musialy otworzyć się na wolny rynek. W konsekwencji uformował się wolnorynkowy mechanizm regulacyjny cen usług uzdrowiskowych, na który wpływa renoma uzdrowiska, jego dostępność komunikacyjna, sezonowość oraz charakter oferty (rodzaj zakwaterowania, wyżywienia, zakres usług leczniczych).

Charakterystyczną dla uzdrowisk imprezą turystyczno-leczniczą jest pobyt wypoczynkowy z fakultatywnymi zabiegami leczniczymi, najczęściej 14-dniowy, zróżnicowany ze względu na rodzaj zakwaterowania, wyżywienia, leczenia itp. Do najczęściej proponowanych form wypoczynku uzdrowiskowego zaliczamy pobyty lecznicze, weekendowe, świąteczno-sylwestrowe, wczasy wypoczynkowe (także z programem odnowy biologicznej), turnusy kondycyjno-odchudzające i rehabilitacyjno-rekreacyjne, kolonie, zimowiska, zielone szkoły, szkolenia i konferencje oraz typowe usługi hotelowe.

Wykształciły się dwa podstawowe kanały sprzedaży rynkowej. W pierwszej kolejności uzdrowiska organizują sprzedaż we wlasnym zakresie, m.in. poprzez targi, ogłoszenia w prasie i Internecie, np. www.ukz-uzdrowisko.krynica. com.pl, www.uzdrowisko-iwonicz.com.pl. W nielicznych przypadkach poprzez stronę WWW można dokonać rezerwacji wybranego produktu turystycznego (Krynica-Żegiestów, Szczawnica). Drugim kanałem są biura podróży, głównie małe i średnie. Oferuja pobyty wypoczynkowe (Holidays, Euro Pol Tour), rzadziej lecznicze, oraz kolonie letnie, zimowiska, zielone szkoły itp. (Elba, Glob, Arizona, Retman). Ta forma dystry-
Currently there are five such Rehabilitation Centres: in Horyniec Zdrój, Iwonicz Zdrój, Kołobrzeg, Jedlec and Szklarska Poreba. They offer about 1000 places altogether.

PFRON (Państwowy Fundusz Rehabilitacji Osób Niepetnosprawnych - State Fund for the Rehabilitation of the Disabled) does not have its own rehabilitation facilities in spas but subsidizes treatment and rehabilitation stays. Subsidies are offered to those over 16 who have been granted a disability 'certificate', are unable to work in agriculture, or receive a special nursing care. The subsidy lies between $25 \%$ and $100 \%$ of the lowest salary. Those in a difficult financial situation and the severely disabled are given priority.

Changes in the regulations regarding subsidized stays in sanatoria have resulted in a considerable fall in the number of patients. In order to fill the vacancies spas have had to open themselves to the free market. As a result a free-market mechanism regulating the prices for spa services has developed depending on the spa's reputation, its accessibility, seasonality and the type of offer (type of accommodation, food and range of treatments).

Tourist-therapeutic demand is typical for spas, a recreational stay combined with treatment, usually lasting 14 days, and varying as far as the type of accommodation, food and treatment, etc. are concerned. Among the most frequent forms of spa recreation are therapeutic, weekend, short-term holidays (including a 'biological' renewal programme), fitness and slimming courses, rehabilitation and recreational, summer and winter holidays, green schools, training courses, conferences and normal hotel services.

There are two basic sales channels. Above all spas organize sales themselves through fairs, the press and internet advertisements, e.g. www.ukz-uzdrowisko. krynica.com.pl or www.uzdrowisko-iwonicz. com.pl. In some cases it is possible to make a reservation for a given tourist product through a website (Krynica-Żegiestow, Szczawnica). The other channel is through tourist offices, mainly of a small and medium size. They offer 
bucji dopiero się rozwija (LAZARKOWIE 2002). W roku 2001 pojawilo się na rynku biuro podróży Vital-Tour, której udziałowcem jest Unia Uzdrowisk Polskich. Biuro specjalizuje się w promocji zdrowia i organizowaniu wyjazdów do polskich uzdrowisk. Docelowo sieć Vital-Tour ma być największym organizatorem i dystrybutorem ofert uzdrowiskowo-turystycznych oraz pierwszym internetowym touroperatorem uzdrowiskowym w Polsce. W przyszłości firma chce rozszerzyć działalność o zagraniczną turystyke przyjazdowa, organizowaną we współpracy z zagranicznymi kasami chorych.

\section{KONIECZNOŚĆ WPROWADZENIA RYNKOWYCH ZASAD DZIAŁANIA}

Polskie uzdrowiska, by sprostać rosnącym wymaganiom rynku, muszą wprowadzić rynkowe zasady działania, szczególnie w sferze promocji uslug uzdrowiskowych oraz powiązanych z nią procesów akredytacji i certyfikacji.

Współczesna promocja uzdrowiskowa rzadko jest poprawna. Najczęstszymi błędami jest utożsamianie promocji z reklamą, brak ciągłości działań promocyjnych, niedostateczny zasób informacji i brak profesjonalizmu materialów promocyjnych. Uzdrowiska rzadko promują się wspólnie lub grupami. Najpowszechniejszą formą promocji są foldery reklamowe zawierające minimalną ilość informacji (klimat, zabiegi, konkretne sanatorium). Dlatego też najpopularniejsze na rynku są miejscowości $z$ długą tradycją uzdrowiskowa lub znane potencjalnym klientom z innych źródel i oryginalnych atrakcji (tab. II). Najczęściej stosowaną przez uzdrowiska formą reklamy jest reklama drukowana (broszury reklamowe). Za wyborem tego nośnika przemawiają niższe, w porównaniu z reklamami telewizyjnymi, koszty. Na polskim rynku istnieje obecnie zaledwie jedno czasopismo w całości poświęcone problematyce uzdrowisk - kwartalnik „Gazeta Zdrojowa". Uzdrowiska reklamują się równocześnie w czasopismach turystycznych („Podróże”), branżowych (np. „Zdrowie”, ,Rehabilitacja”) i lokalnych gazetach codziennych oraz na internetowych serwerach turystycznych.

Rzadkością jest wykorzystywanie sponsoringu jako elementu promocji, pomimo że stanowi on doskonałą okoliczność sprzyjającą upowszech- recreational breaks (Holidays and Euro Pol Tour), and less often therapeutic ones, as well as summer and winter holidays, and green schools for school students, etc. (Elba, Glob, Arizona and Retman). This form of distribution has just begun to develop (EAZARKOWIE 2002). In 2001 the Vital-Tour tourist office appeared on the market whose shareholder is the Polish Spas Union. The office specializes in health promotion and organizing holidays in Polish spas. Vital-Tour is becoming the largest organizer and distributor of spa and tourist offers, as well as the first internet spa tour-operator in Poland. In the future the firm is planning to expand its activity through incoming foreign tourism organized in co-operation with foreign national health services.

\section{THE NECESSITY OF INTRODUCING MARKET STANDARDS}

In order to adjust to market requirements, Polish spas must introduce market standards especially in the promotion sector and the related processes of accreditation and certification.

Currently, spa promotion is hardly ever appropriate. The most frequent mistakes are confusing promotion with advertising, lack of promotional continuity, insufficient information and a lack of professionalism in promotional materials. Spas rarely promote themselves jointly. The most popular form is an advertising leaflet which provides minimum information (climate, treatment at a given sanatorium) and that is why the most popular spas on the market are those with a long tradition or familiar to potential clients from other sources, and with special tourism attractions (table II). The most popular form of advertising is a leaflet as it is cheaper than a TV commercial. There is only one magazine devoted wholly to spas on the Polish market: the quarterly Gazeta Zdrojowa. Spas advertise themselves in tourist magazines (Podróże), specialized magazines (e.g. Zdrowie, Rehabilitacja), local daily newspapers and on internet tourism servers. 
nianiu informacji o prowadzonej działalności i zakresie świadczonych usług. Tę formę upodobało sobie uzdrowisko Wysowa, sponsorujące szereg imprez kulturalnych w swoim regionie oraz inne organizacje (Zespoly Terapii Zajęciowej, Klub Piłkarski Górnik Zabrze). Do najczęściej sponsorowanych podmiotów należą lokalne kluby piłkarskie, imprezy sportowe oraz wydarzenia kulturalne, tj. Dni Miasta, festiwale, przeglady artystyczne.
It is rare to use sponsorship as a promotional element, although it is a perfect way of spreading information about the services provided. This form of promotion is used by Wysowa spa which sponsors a number of cultural events in the region as well as other organizations (Activity Therapy Teams, Górnik Zabrze Football Club). Football clubs, sports events and cultural events, like town festivals, music or art festivals are most frequently sponsored.

T a b e la II. Najbardziej i najmniej popularne uzdrowiska w ocenie kuracjuszy

T a b I e II. The most and the least popular spas in the opinion of patients

\begin{tabular}{|c|c|c|}
\hline \multirow{2}{*}{ Miejsce } & \multicolumn{2}{|c|}{ Uzdrowiska wybierane przez kuracjuszy } \\
\cline { 2 - 3 } & najczęsciej & najrzadziej \\
\hline \multirow{2}{*}{$\begin{array}{c}\text { Place/ } \\
\text { location }\end{array}$} & \multicolumn{2}{|c|}{ Spas selected by patients } \\
\hline & most frequently & least frequently \\
\hline 1 & Kołobrzeg & Wapienne \\
\hline 2 & Krynica & Sopot \\
\hline 3 & Ciechocinek & Swoszowice \\
\hline 4 & Polanica & Konstancin \\
\hline 5 & Ustrón & Augustów \\
\hline 6 & Iwonicz & Jedlina \\
\hline 7 & Ladek & Solec \\
\hline 8 & Swinoujście & Przerzeczyn \\
\hline 9 & Ustka & Rymanów \\
\hline 10 & Szczawnica & Goczałkowice \\
\hline
\end{tabular}

Żródło/S o ur c e: HAZUKA (1999).

Uczestnictwo w targach pozwala zaprezentować ofertę obszernemu gronu potencjalnych klientów przy niskich kosztach własnych. Corocznie, od 1994 r., organizowane są w Polanicy Zdroju Międzynarodowe Targi Turystyczno-Uzdrowiskowe Natura Sanat, których głównym celem jest promocja uzdrowisk, gmin turystycznych, miejscowości wczasowych oraz przegląd możliwości leczniczych, bazy hotelowej i gastronomicznej uzdrowisk. Uzdrowiska biorą również udział $w$ typowych targach turystycznych, np. TT Warsaw, Krakowski Salon Turystyczny lub Berlińskie Targi Turystyczne i Międzynarodowe Targi Turystyczne Ukrainy w Kijowie.

Pozytywny image uzdrowisk umacnia posiadanie certyfikatów jakości. W Polsce funkcjonuje Centrum Monitorowania Jakości w Ochronie Zdrowia, jednakże żaden szpital ani sanatorium nie poddało się dotychczas jego ocenie akredytacyjnej. Funkcjonują dwa systemy oceny ze-
Taking part in fairs gives an opportunity to present the offer to a large group of potential clients at a low cost. Ever year, since 1994, Polanica Zdrój has been organizing Natura Sanat International Tourist and Spa Fairs, whose main aim is to promote spas, tourist gminas, holiday resorts and to present a review of possible treatments, hotels and restaurants. Spas also participate in typical tourist fairs such as TT Warsaw, Krakow Tourist Salon or the Berlin Tourist Fair and the Ukraine International Tourist Fair in Kiev.

The positive image of spas is enhanced by quality certificates. In Poland there is the Centrum Monitorowania Jakości $w$ Ochronie Zdrowia (Health Care Guality Monitoring Centre), however no hospital or sanatorium has ever undergone its evaluation. There are two systems of 
wnętrznej: EFQM (Europejska Nagroda za Jakość w Medycynie), stosowana głównie w Belgii i Holandii, oraz system zarządzania jakością ISO, stosowany m.in. w niemieckich i włoskich placówkach medycznych. Szerokim wachlarzem atestów dysponuja produkty uzdrowiskowe. Najbardziej efektownym przykladem jest naturalna woda mineralna Piwniczanka: atest Zdrowa Zywność Atestowana, znak Najwyższa Jakość Malopolska i Srebrna Tarnina. Woda została ogólnopolskim laureatem znaku Polski Producent, otrzymała także główną nagrodę VIII Targów Hoteli i Gastronomii i srebrny medal IV Międzynarodowych Targów Spółdzielczości (KIDOŃ 2002).

Polskie uzdrowiska potrzebują spójnej akcji promocyjnej, prowadzonej zgodnie $\mathrm{z}$ zasadami marketingu, profesjonalnie i systematycznie. Na barki Polskiej Organizacji Turystycznej i ogólnopolskich stowarzyszeń uzdrowiskowych spada obowiązek jak najszybszego opracowania krajowej strategii marketingowej dla uzdrowisk. Pierwszym krokiem jest uczynienie $\mathrm{z}$ uzdrowisk narodowego produktu markowego. Poszczególne uzdrowiska powinny rozpocząć wdrażanie metod menedżerskich w zarządzaniu. Koniecznością jest doskonalenie jakościowe kadry, podnoszenie kultury obshugi turystów i zwiększenie znajomości języków obcych wśród kadry bezpośrednio kontaktującej się z klientami (głównie w hotelarstwie, gastronomii i zabiegach medycznych). Wydawnictwa promocyjne (informatory, ulotki) muszą być wydawane w wersjach wielojęzycznych i zawierać istotne dla potencjalnego klienta informacje odnośnie do standardu, wyposażenia, atrakcji i przede wszystkim cen ushug.

Aktywizacji sprzyjają inicjatywy lokalnych samorządów i przedsiębiorców lokalnych, np. powołanie lokalnych organizacji turystycznych, odpowiedzialnych za promocję i informację, jak również plany opracowania i realizacji monitoringu wraz $\mathrm{z}$ opartym na nim komputerowym banku informacji o obiektach, miejscowościach i gminach uzdrowiskowych, których zakres będzie wykraczać poza układy branżowe i dotyczyć całych jednostek terytorialnych lub ich wydzielonych autonomicznych części funkcjonalno-przestrzennych (JAGUSIEWICZ 1998). Ułatwi to włączenie uzdrowisk do ogólnokrajowego systemu informacji oraz sieci rezerwacji i dystrybucji usług turystycznych i hotelowych w kraju i za granica. outside evaluation: EFQM (European Foundation for Quality Management) used mainly in Belgium and the Netherlands, as well as the ISO quality management system, used in German and Italian medical institutions. Spa products can boast a wide range of certificates. The most spectacular example here is the Piwniczanka natural mineral water, which has Zdrowa Żywność Atestowana - certified healthy food, and Malopolska Najwyższa Jakość and Srebrna Tarnina certificates. The water received the Polski Producent label, as well as the main prize at the $8^{\text {th }}$ Hotel and Catering Fair and the silver medal at the $4^{\text {th }}$ International Co-operative Fair (KIDON 2002).

Polish spas need joint promotional action, based on marketing principles and conducted in a professional and systematic way. The Polish Tourist Organization and national spa societies should be responsible for preparing a marketing strategy. The first step is to make spas a national brand and individual spas should start implementing managerial methods. It is necessary to raise employee qualifications, improve service and popularise language learning among those employees who directly contact the clients (mainly in the hotel industry, catering and treatment procedures). Promotion publications (booklets and leaflets) must appear in several languages and contain information regarding the standard, equipment, tourism attractions and prices important to a potential client.

The support of local authorities and entrepreneurs is invaluable in this process, and includes establishing local tourist organizations responsible for promotion and information, devising and introducing a monitoring system along with a computerized database concerning spa facilities, resorts and gminas. This information would involve whole local authorities or their individual autonomous functionalspatial parts (JAGUSZEWICZ 1998). It would help incorporate spas into the national information system, as well as the tourist and hotel reservation and distribution network in both Poland and abroad. 


\section{TURYSTYKA UZDROWISKOWA}

Ostatnim niezwykle ważnym problemem okresu transformacji okazuje się być wspólistnienie lecznictwa i turystyki. Ścisłe przenikanie funkcji leczniczych i turystyczno-wypoczynkowych niejednokrotnie nabiera cech nieporozumień. Przeciwstawne cele, zróżnicowana długość pobytu i form spędzania wolnego czasu turystów i kuracjuszy warunkują owe kontrowersje. Konflikty powodują przestrzenne nakladanie się lub sąsiedztwo obszarów aktywności poszczególnych grup, przestrzenna i czasowa koncentracja ruchu, problemy komunikacyjne (wadliwy układ komunikacyjny, ograniczona pojemność i liczba parkingów) oraz zagospodarowanie uzdrowisk (PTASZYCKA-JACKOWSKA 1999).

Turystyka w uzdrowiskach przyjmuje zróżnicowane formy: wypoczynkową (wczasy, kolonie, zimowiska, pobyty weekendowe, zielone szkoły, inne stacjonarne formy wypoczynku), specjalistyczną (piesza, rowerowa, narciarska, wodna), kulturową (w miejscach historycznych) oraz kongresową. Niektóre uzdrowiska karpackie, dzięki przygranicznemu położeniu, pełnią ponadto funkcję tranzytową (Muszyna, Piwniczna) lub funkcję węzla komunikacyjnego (Rabka).

Współwystępowanie funkcji leczniczej oraz wypoczynkowo-turystycznej jest korzystne gospodarczo zarówno dla uzdrowiska, jak i samej miejscowości. Pozwala na całoroczne wykorzystanie urządzeń zabiegowych, gastronomicznych, handlowych, uslugowych, bazy mieszkaniowo-wczasowej, niwelując niekorzystne oddziaływanie sezonowości. Mimo wszystko postuluje się ograniczenie rozmiaru niektórych formy ruchu turystycznego ze względu na ich szkodliwy wpływ na środowisko (np. turystyka zmotoryzowana i masowa). Do form pożądanych zalicza się turystykę alternatywną i zrównoważoną.

$\mathrm{Na}$ polu dyskusji dotyczących miejsca turystyki w uzdrowiskach ścierają się dwa głosy. Środowiska medyczne zdecydowanie przeciwstawiają się planom rozwoju turystyki na większą skalę. W ich mniemaniu medycyna powinna stanowić priorytet przed turystyka, czyli uzdrowiska należy nakierować na świadczenie specjalistycznych usług medycznych, zachować szpitale uzdrowiskowe, kliniki i inne ośrodki lecznictwa zamkniętego. Diametralnie odmienne stanowisko prezentują samorządy terytorialne, przedstawiciele orga-

\section{SPA TOURISM}

An extremely important problem of the transformation period is the co-existence of therapy and tourism. The overlapping of therapeutic and tourist functions often causes misunderstandings. Contradictory aims, the differing lengths of stay and ways of spending free time by both tourists and patients lead to these controversies. Conflicts are caused by spatial overlapping or close vicinity of the activity areas of differing interests, the space-time tourism concentration, transport problems (inadequate transportation system, limited capacity and number of car parks) and the spa infrastructure (PTASZYCKA-JACKOWSKA 1999).

Spa tourism takes on a variety of forms: recreational (holidays, children's summerand winter holidays, weekend breaks, green schools, other forms of recreation), specialist (walking, cycling, skiing, water sports), cultural (at historical sites) and conference. Some Carpathian spas, due to their border location, also perform a transit function (Muszyna and Piwniczna) or function as a transport node (Rabka).

From the economic point of view, the co-occurrence of therapeutic and tourist functions is beneficial for both the spa and the resort itself. Medical facilities, restaurants, shops, services and accommodation are exploited all year round, and the negative effects of seasonality are minimal. Despite this, it has been suggested that some forms of tourism should be limited due to their harmful influence on the natural environment (e.g. vehicles and mass tourism). Among the forms which are welcome are alternative and sustainable tourism.

In the discussion on the place of tourism in spas, two viewpoints can be distinguished. Medical circles strongly oppose large-scale tourism development plans. In their opinion therapy should be a priority and spas should be oriented towards specialized medical services, and spa hospitals, clinics and other indoor treatment centres should be preserved. A completely different approach is presented by the local authorities, 
nizacji skupiających uzdrowiska, przedstawiciele turystyki, lokalni przedsiębiorcy, usługodawcy i mieszkańcy zainteresowani rozwojem miejscowości uzdrowiskowych. Argumentują, iż uzdrowiska należy traktować holistycznie, wraz ze społecznością, której turystyka zapewnia korzyści materialne i społeczne. Jej rozwój generuje przedsiębiorczość, miejsca pracy, dodatkowe dochody, wplywa na poprawę infrastruktury i popularność miejscowości, niesie zapotrzebowanie na inne usługi (transport, rozrywka, handel, usługi specjalistyczne) (WóJcıK 2001). Stanowi mechanizm samo się napędzający.

W interesie wszystkich zainteresowanych istnieniem i rozwojem uzdrowisk leży osiagnięcie porozumienia. Usługi świadczone w zakresie nowoczesnej medycyny są i zawsze będą skorelowane $\mathrm{z}$ sektorem turystycznym, zwłaszcza w płaszczyźnie rynkowej, materialnej i bytowej. Traktowanie lecznictwa i turystyki jako dziedzin integralnych umożliwi ujęcie ich jako istotnego i specyficznego segmentu turystyki uzdrowiskowej, jednego z najdynamiczniej rozwijających się segmentów rynku usług turystycznych na świecie.

\section{PRZYPISY}

\footnotetext{
'Obszar, w którym lokalizuje się urządzenia lecznicze, mający chronić warunki naturalne uzdrowiska; Dzieli się go na trzy koncentryczne strefy: $A, B$ i C.

${ }^{2}$ Obejmuje bezpośrednio dzielnicę lecznictwa uzdrowiskowego.

${ }^{3}$ Najczęściej miejscowość w granicach administracyjnych.

${ }^{4}$ Tereny, których sposób zagospodarowania ma decydujacy wplyw na warunki klimatyczne i naturalne uzdrowiska.
}

representatives of spa organizations, tourism representatives, local entrepreneurs, service providers and inhabitants interested in the development of spas. They argue that spas should be treated holistically, together with their communities who benefit from tourism materially and socially. Its development generates business, jobs, additional income, improves infrastructure and increases popularity as well as the demand for other services (transport, entertainment, commerce, specialized services) (WÓJCIK 2001). It is a self-driving mechanism.

Reaching an agreement would be beneficial for all those interested in the preservation and development of spas. Modern therapeutic services are and will always be correlated with the tourist sector, particularly in terms of market, material and social aspects. Treating therapy and tourism in an integrated way will make it possible to approach them as a significant element of spa tourism, and as one of the most dynamic segments of the world tourist market.

\section{FOOTNOTES}

${ }^{1}$ An area where treatment facilities are located, which is to protect the spa's natural conditions; it is divided into three concentric zones: $\mathrm{A}, \mathrm{B}$ and $\mathrm{C}$.

${ }^{2}$ Directly covers the spa treatment district. ders.

3 Usually a destination within its administrative bor-

${ }^{4}$ Areas where the infrastructure seriously affects the climatic and natural conditions of the spa.

\section{BIBLIOGRAFIA - BIBLIOGRAPHY}

GolBA J., 2002. Aktywizacja społeczno-gospodarcza gmin uzdrowiskowych jako podstawa ich rozwoju, maszynopis referatu na XI Kongres Uzdrowisk Polskich.

HANDZEL J., 2001, Sytuacja ekonomiczno-finansowa spótek lecznictwa uzdrowiskowego i podmiotów branżowych prowadzacych lecznictwo uzdrowiskowe $w$ regionie małopolskim, „Jedziemy do Wód”, nr 3, s. 58-59.

Informacja o wynikach kontroli przekształceń własnościo wych zakładów lecznictwa uzdrowiskowego, 2002, NIK, Warszawa, http://www.nik.gov.pl.

HAZUKA W., 1999. Aspekty prawne lecznictwa uzdrowiskowego, [w:] Boruszczak M. (red.), Turystyka uzdrowiskowa - stan i perspektywy: I miedzynarodowa konferencja naukowa, Jastrzebia Góra, 3-5.09.1999. Zbiór materiałów pokonferencyjnych, Gdańsk, s. 76-79.
Jagusiewicz A., 1998, Problemy lecznictwa i turystyki $w$ uzdrowiskach polskich. Instytut Turystyki, Warszawa, $42 \mathrm{~s}$.

JAGUSIEWICZ A., 2002, Infrastruktura turystyki uzdrowiskowej w Polsce, Instytut Turystyki, Warszawa, 46 s.

KIDON E., 2002, Zasady kształtowania uzdrowisk Beskidu Sadeckiego $w$ świetle idei zrównoważonego rozwoju. praca doktorska, Zakład Gospodarki Turystycznej i Uzdrowiskowej UJ, Kraków.

LAZARKOWIE M. R., 2002, Gospodarka turystyczna, WSE, Warszawa, $226 \mathrm{~s}$.

PRZYBYLSKI M., 2004, Tylko pięć na sprzedaż, Rzeczpospolita, nr 78, www.rzeczpospolita. pl/szukaj/gazeta_ online.pl. 
PTASZYCKA-JACKOWSKA D., 1999, Lecznictwo uzdrowiskowe a turystyka, „Turyzm”, t. 9, z. 1, s. 201-207.

Rehabilitacja rentowa $w$ ramach prewencji rentowej ZUS, 17 XII 2004, http://www.zus.pl/swiadcze/rehab.htm.

Rehabilitacja, 17 XII 2004, http://www.krus.gov.pl/ document.php?id=141.

Ustawa o lecznictwie uzdrowiskowym, uzdrowiskach $i$ obszarach ochrony uzdrowiskowej oraz o gminach uzdrowiskowych (Dz U, 2005, nr 167, poz. 1399).

Ustawa o uzdrowiskach $i$ lecznictwie uzdrowiskowym (Dz U, 1966, nr 23, poz. 150 z późn. zm.).

Uzdrowiska - terminologia, klasyfikacja i wymagania ogólne, 2001, Polski Komitet Normalizacyjny, PN-Z-11000: 2001, Warszawa, 9 s.
WOLOWIEC T., 2002, Kontrowersje podatkowe-podatek od nieruchomości: sanatoria i inne zaktady opieki zdrowotnej - działalność gospodarcza czy pozostała? "Jedziemy do Wód", nr 1, s. 45-53.

WOLOWIEc T., 2003a, Konkurencyjność polskich uzdrowisk $i$ lecznictwa uzdrowiskowego $w$ warunkach integracji z Uniq Europejska, "Jedziemy do Wód”, nr 2, s. 68-78.

WotowiEc T., 2003b. Ocena procesu przeksztatcen wtasnościowych zakładów lecznictwa uzdrowiskowego $w$ swietle wyników kontroli NIK, "Jedziemy do Wód". nr 2, s. 79-95.

Wóscik G., 2001, Miejsce turystyki uzdrowiskowej $w$ przemyśle turystycznym regionu, „Jedziemy do Wód”, nr 3 , s. $54-55$. 